\title{
Role of wild mammals in traditional medicine and mystic practices in the province of Oubritenga, Burkina Faso
}

\author{
Daogo OUOBA ${ }^{1,2,3^{*}}$, Ollo Théophile DIBLONI ${ }^{2}, \mathrm{Komandan} \mathrm{MANO}^{3}$, \\ Yampoadiba OUOBA ${ }^{4}$ and Boureima Gustave $\mathrm{KABRE}^{3}$
}

\begin{abstract}
${ }^{1}$ Ministère de l'Environnement, de l'Economie Verte et du Changement Climatique (MEEVCC), Secrétariat Permanent du Conseil National pour le Développement Durable (SP-CNDD), 01 BP 6486 Ouagadougou 01, Burkina Faso.

${ }^{2}$ Centre National de Recherches Scientifiques et Technologiques (CNRST), Institut de l'Environnement et de Recherches Agricoles (INERA), Centre de Recherches Environnementale, Agricole et de Formation de Kamboinsé (CREAF-Kamboinsé), Département Environnement et Forêts (DEF), 01 BP 470 Ouagadougou 01, Burkina Faso.

${ }^{3}$ Université Joseph Ki -Zerbo, Unité de Formation et de Recherche en Science de la Vie et de la Terre (UO / UFR-SVT), Laboratoire de Biologie et Ecologie Animale (LBEA), 03 BP 7021 Ouagadougou 03, Burkina Faso.

${ }^{4}$ Ministère de l'Environnement, de l'Economie Verte et du Changement Climatique (MEEVCC), Secrétariat Général (SG), Ecole Nationale des Eaux et Forêts (ENEF), 01 BP1105 Bobo-Dioulasso 01, Burkina Faso.

*Corresponding author; E-mail: daogoleon@yahoo.fr, Telephone: (+226) 70650249
\end{abstract}

\begin{abstract}
Local people use corpses and organs of wild animals for medical care and mystical practices. The study aims to inventory the mammal's species which organs are used for the treatment of some diseases or the implementation of some mystical practices. It was an ethnozoological survey which took place from September to December 2018 in 11 markets with 18 traditional practitioners selling wild mammal products. In total, 24 species of wild mammals have been identified and 16 organs listed as medicine for cure 21 diseases. Some of these organs are also involved in 7 mystical practices of local people. Animal parts such as the skin (51.30\%) and the bones / the horns (16.23\%) are the most sought after on the markets. Traders sources are mainly from Burkina Faso (92.57\%) and to a lesser extent from Niger (7.43\%). Almost all the concerned species are protected (22 species) in Burkina Faso. Among these species, 4 are vulnerable according to the IUCN criteria. The obvious consequence of these traditional needs for corpses and parts of wild mammals collected by local communities is undoubtedly the depletion of biodiversity. Therefore, this requires the application of conservation rules which guarantee better exploitation of these biological resources.
\end{abstract}

(C) 2020 International Formulae Group. All rights reserved.

Keywords: Biodiversity, wildlife, traditional use, animal's organ, ethnozoology

\section{INTRODUCTION}

Using animals and their products to treat patients suffering from a range of health conditions has a long history and is still common in many parts of the world (Alade et al., 2018; Jugli et al., 2019). According to several authors, this traditional utilization does not end to curing diseases, but is also known in the field of mystical practices (Nasi et al., 2011; Alves et al., 2012; Camino et al., 2018). Castillo and Ladio, (2019) add that these traditional uses involve at the same time 
domestically and wild animals. For Alves and Alves (2011), the medicinal fauna is largely based on wild animals, including some endangered species.

In many African countries, studies have proved the utilization of wild animals and plants in traditional medicine (Yaokokorebeibro et al., 2010; Nasi et al., 2011; Djagoun et al., 2012; McNamara et al., 2016; Ajagun and Anyaku, 2017; Djagoun et al., 2018 ; Yolidje et al., 2020). In Africa, traditional medicine is one of the richest cultures that people have developed, conserved and passed on from one generation to another (Rivière et al., 2005). The modern medicine effectiveness and the influence of revealed religions have not stopped these empirical practices which remain strong and even in marked progression (Djagoun et al., 2012). In order to cure some diseases or to provide some desired effects, the populations rely on wildlife parts. Wild animals are killed because of conflicts or to use their products in traditional medicine and other traditional practices (Djagoun et al., 2012; McNamara et al., 2016; Djagoun et al., 2018, Kouao et al., 2018). However, many of these animals benefit from protection and surveillance in the protected areas. The hunting of wild animal for medicinal and / or mystical aims is on the way to becoming one of the principal factor of biodiversity loss (Alves and Alves, 2011; Ferreira et al., 2013).

These traditional knowledges related to wild animals are also practiced by people in Burkina Faso. Wild animals' products are sold by traditional practitioners in the markets. These sellers are supplied by products dealers. Unfortunately, little or no work has been done to ascertain the different animal species commonly used in traditional medicine. For this reason, there is a lack of data to support policy decision in terms of the regulation of the activity in general. In addition, the lack of studies on wildlife parts for trade restricts an evaluation of the impact of this activity on the exploited species (Ferreira et al., 2013).

In Burkina Faso, few studies looked into the use of wildlife products in traditional medicine and traditional and mystical practices (Dibloni, 2003; Dibloni et al., 2009; Dibloni, 2011; Dibloni et al., 2013; Ouoba, 2019). Among the authors cited, Ouoba (2019) research led to conducting this current study by providing baseline information on the species within the study area and the culture of the local population, their mystical practices and traditional medicine. Other studies where carried out on three specific species including hippopotamus (Hippopotamus amphibius), roan antelope (Hippotragus equinus) and hartebeest (Alcelaphus buselaphus), (Dibloni, 2003; Dibloni et al., 2009; Dibloni, 2011; Dibloni et al., 2019). These studies also discuss the importance of species such as Erythrocebus patas, Phacochoerus africanus and Hystrix cristata in mystical practices (Dibloni et al., 2013).

It has been demonstrated that the use of species of high value in traditional medicine reduces their reproductive rates (Kakati et al., 2006). Consequently, Species with these life history traits are considered more prone to extinction and may therefore be less resilient to harvest (Kakati et al., 2006). For example, Primates: Most persecuted of animals - hunted for their meat, fur and animal medicine-based (Mittermeier et al., 2007).

The objective of this study was to give an overview of the medicinal wild mammals' products traffic, to provide information on utilization of these biological and genetic resources in traditional medicine and mystical practices, and to discuss the implication of this practice for a sustainable conservation and use of biodiversity.

\section{MATERIALS AND METHODS Study area}

The province of Oubritenga belongs to the region of the "Plateau Central", Burkina Faso. It is located between $2^{\circ} 15^{\prime}$ and $0^{\circ} 20^{\prime}$ longitudes West and $11^{\circ} 45^{\prime}$ and $13^{\circ} 00^{\prime}$ North (Figure 1). It covers about $2,841.112 \mathrm{~km}^{2}$ with a population of about 324,000 inhabitants (INSD, 2009a). This population is mainly represented by Mossi, Fulani and Bissas ethnic groups. More than $80 \%$ of them practice agriculture, breeding, vegetable farming and the exploitation of forest resources (INSD, 2015).

The Oubritenga is part of the SudanoSahelian tropical climate and is characterized by two seasons: a rainy season (June to September) and a dry season (October to May). 
The rainfall is erratic and the annual average varies between 750 to $850 \mathrm{~mm}$ per year. The ambient temperature varies widely. It is low (minimum: $15{ }^{\circ} \mathrm{C}$ ) during cool months such as December and January and high (maximum: 45 $\left.{ }^{\circ} \mathrm{C}\right)$ during hot months from March to May (Kaboré et al., 2007).

The area's vegetation is essentially shrub savannah but woody savannahs and sparse gallery forests can be found along the main rivers such as the Nakambé, the Massili, the Koulottoko, the Nazinon, the BougoulaMoudi, the Bombore and the Guibga. Floristic species include Vitellaria paradoxa, Parkia biglobosa, Lannea microcarpa, Tamarindus indica, Adansonia digitata, Acacia senegal, Anogeissus leocarpa and Pterocarpus erinaceus. This rich floristic nature is inhabited by small mammals (Ourebia ourebi, Chlorocebus aethiops, Erythrocebus patas, Lepus victoriae, Cricetomys gambianus, Euxerus erythropus, etc.), reptiles (Varanus niloticus, Varanus exanthematicus, Crocodylus niloticus, Naja nigricollis, etc.), and birds (Accipiter badius, Pternistis bicalcaratus, Bucorvus abyssinicus, Tockus erythrorhynchus, etc.) (INSD, 2009b).

\section{Data collection and analysis}

To achieve the objectives of the study, the data collection and analysis methods used are based on previous similar studies conducted in the world.

\section{Data collection}

An inventory coupled with semistructured interviews was done (Albuquerque et al., 2014; Djagoun et al., 2012; Martinez, 2013; Djagoun et al., 2018) in the public markets of Absouya, Bissiga, Dapélogo, Donsé, Loumbila, Manéga, Nagréongo, Tankounda, Ziniaré, Zitenga and Zoundi (Figure 1), from September to December 2018. It was designed following two steps. Firstly, a prospecting study on the field was conducted. It allowed to find 11 markets in which there is at least one wildlife products seller. The second step was to make an inventory and interviews with all sellers found in the markets. There were 18 respondents overall in the 11 markets. They all belong to the "Mossi" ethnic group and consist of 16 men and 2 women. They were between 40 and 80 years old. Among these actors, $28 \%$ were farmers, pastoralists and traditional healers, $60 \%$ were farmers, traditional healers, $6 \%$ farmers, knitters and traditional healers and $6 \%$ of them were traditional healers (Table 1). The information collected during the interviews are (i) the names in local language of the wild mammal species of which the products are sold by the sellers, (ii) the wild mammal products found on the sellers stalls (Figure 2), (iii) the traditional uses of wild mammal products and (iv) the origins of the wild mammal products found on the sellers stalls.

\section{Species taxonomic identification}

The species taxonomic identification has been done following several approaches. It has first been done based on the names and descriptions given by the wild mammals' products sellers (Castillo et al., 2019). Secondly, wild mammal's identification guides were used to confirm the results (Haltenorth et al., 1985; FAN, 2003; Lamarque, 2004). Finally, when there are still doubts on a species identity, an appropriate sample is taken or photographies are snapped and compared to the specimens collected and deposited in scientific collections that is "Laboratoire d'Histoire Naturelle du Centre National de la Recherche Scientifique et Technologique du Burkina Faso" (Vieira et al., 2014). The species that have not been identified with precision were removed from the study. The scientific names of the species were updated based on the site "Mammal species of the world".

\section{Data analysis}

The quantitative data analysis has combined many approaches used on previous studies (El-Hilal et al., 2003; Martinez, 2013; Kpétéré et al., 2015; Djagoun et al., 2018; Castillo et al., 2019). The collected data were recorded in Microsoft Excel 2010 software and analyzed using the "dynamic cross" table function. The assessment was oriented on the elements below.

$\checkmark$ The wild mammal species of which products are sold in the market

A list of wild mammal species of which products are sold has been obtained by making 
a synthesis of the species identified from all respondents' stalls.

$\checkmark \quad$ The species use value

The species use value is calculated through the formula used in several studies, shown below (Friedman et al., 1986; Phillips and Gentry, 1993 a-b; Albuquerque et al., 2007; Bruce and Timothy, 2007; Cetto and Heinrich, 2011):

$$
\mathrm{UV} \mathrm{i}=\frac{\sum_{i}^{n} U}{\mathrm{n}}
$$

Where: $\mathrm{UVi}=$ species $\mathrm{i}$ use value; $\underline{\sum_{i}^{n} U}=$ Sum of citations of species $i$ and $n=$ number of traditional practioners interviewed

$\checkmark$ The different wild mammals' products sold in the markets

A list of wild mammals' products sold in the markets has been produced making a synthesis of the products identified at all the respondents' stalls. The number of sellers possessing each product has also been determined. $\checkmark$ The different origins of wild mammals' products sold in the markets

For each identified product, its origin was determined. The citation percentage of each origin was calculated. The citation percentage of an origin is the ratio between the number of citations of this origin and the product of the number of products and the number of respondents.

$\checkmark$ The different traditional uses (diseases treatments, mystical practices)

The different diseases treatments and mystical practices were determined by making a synthesis of all the sellers' citations.

\section{Wild mammal species conservation statute}

All the identified species have been confronted to the national regulation of fauna protection list (MEEVCC, 2017), to the red list of the IUCN (2019) and on the appendices of the CITES (2017) with the aim of knowing their conservation statute in Burkina Faso and throughout the world.

Table 1: Socio-demographic characteristics of the respondents.

\begin{tabular}{|c|c|c|c|}
\hline & Variables & Number of respondents & Frequency $(\%)$ \\
\hline \multirow[t]{2}{*}{ Ethnic group } & Mossi & 18 & 100 \\
\hline & Total & 18 & 100 \\
\hline \multirow[t]{3}{*}{ Sex } & Man & 16 & 88.89 \\
\hline & Woman & 2 & 11.11 \\
\hline & Total & 18 & 100 \\
\hline \multirow[t]{5}{*}{ Age group } & {$[40-50[$} & 4 & 22.22 \\
\hline & {$[50-60[$} & 6 & 33.33 \\
\hline & {$[60-70[$} & 4 & 22.22 \\
\hline & {$[70-80[$} & 4 & 22.22 \\
\hline & Total & 18 & 100 \\
\hline \multirow[t]{5}{*}{$\begin{array}{l}\text { Main } \\
\text { activities }\end{array}$} & $\begin{array}{l}\text { Agriculture }+ \text { breeding }+ \\
\text { traditional healing }\end{array}$ & 5 & 27.78 \\
\hline & $\begin{array}{l}\text { Agriculture + traditional } \\
\text { healing }\end{array}$ & 11 & 61.11 \\
\hline & $\begin{array}{l}\text { Agriculture + weaving + } \\
\text { traditional healing }\end{array}$ & 1 & 5.56 \\
\hline & Traditional healing & 1 & 5.56 \\
\hline & Total & 18 & 100 \\
\hline
\end{tabular}




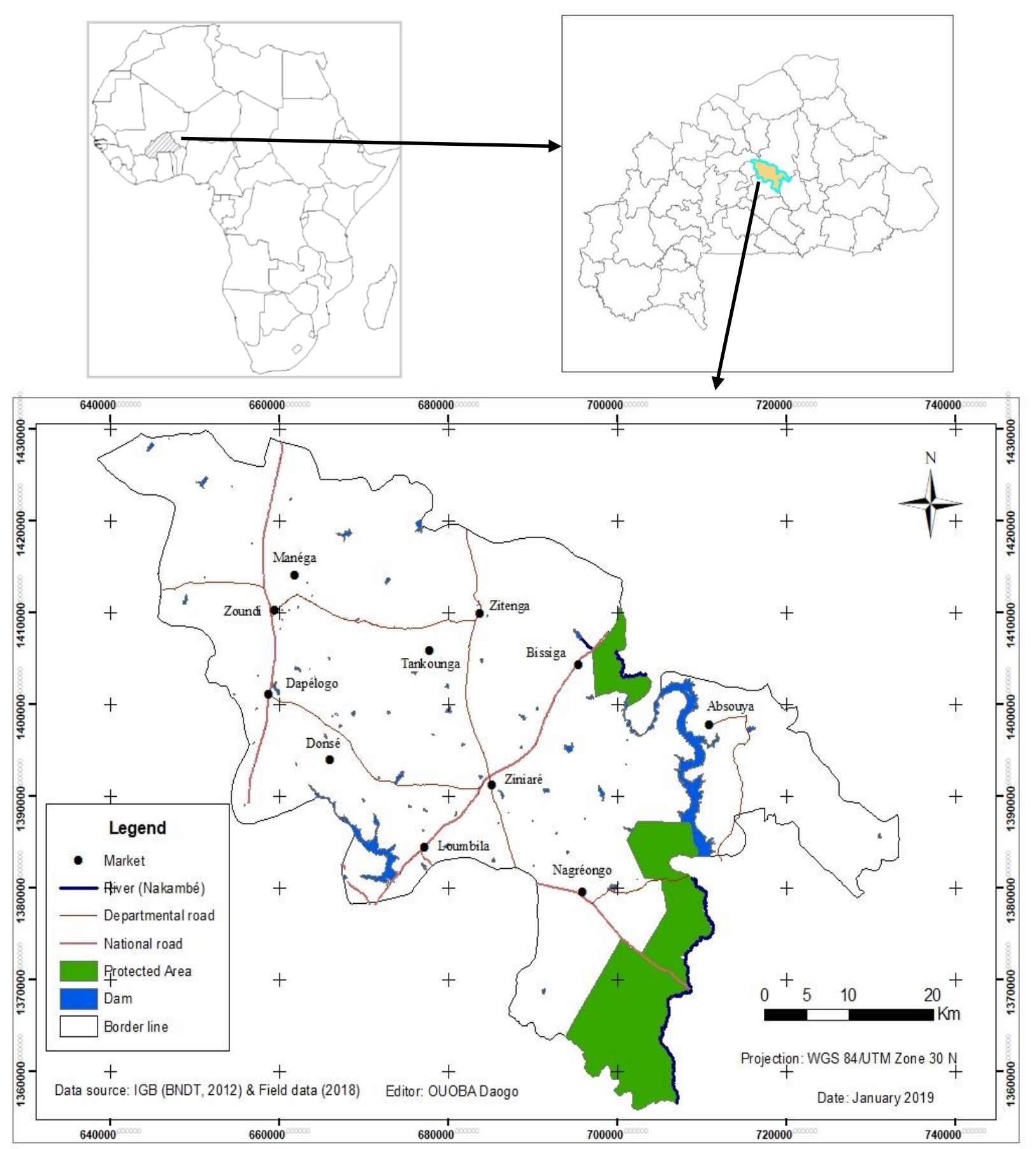

Figure 1: Location map of the province of Oubritenga and markets where surveys were conducted. 


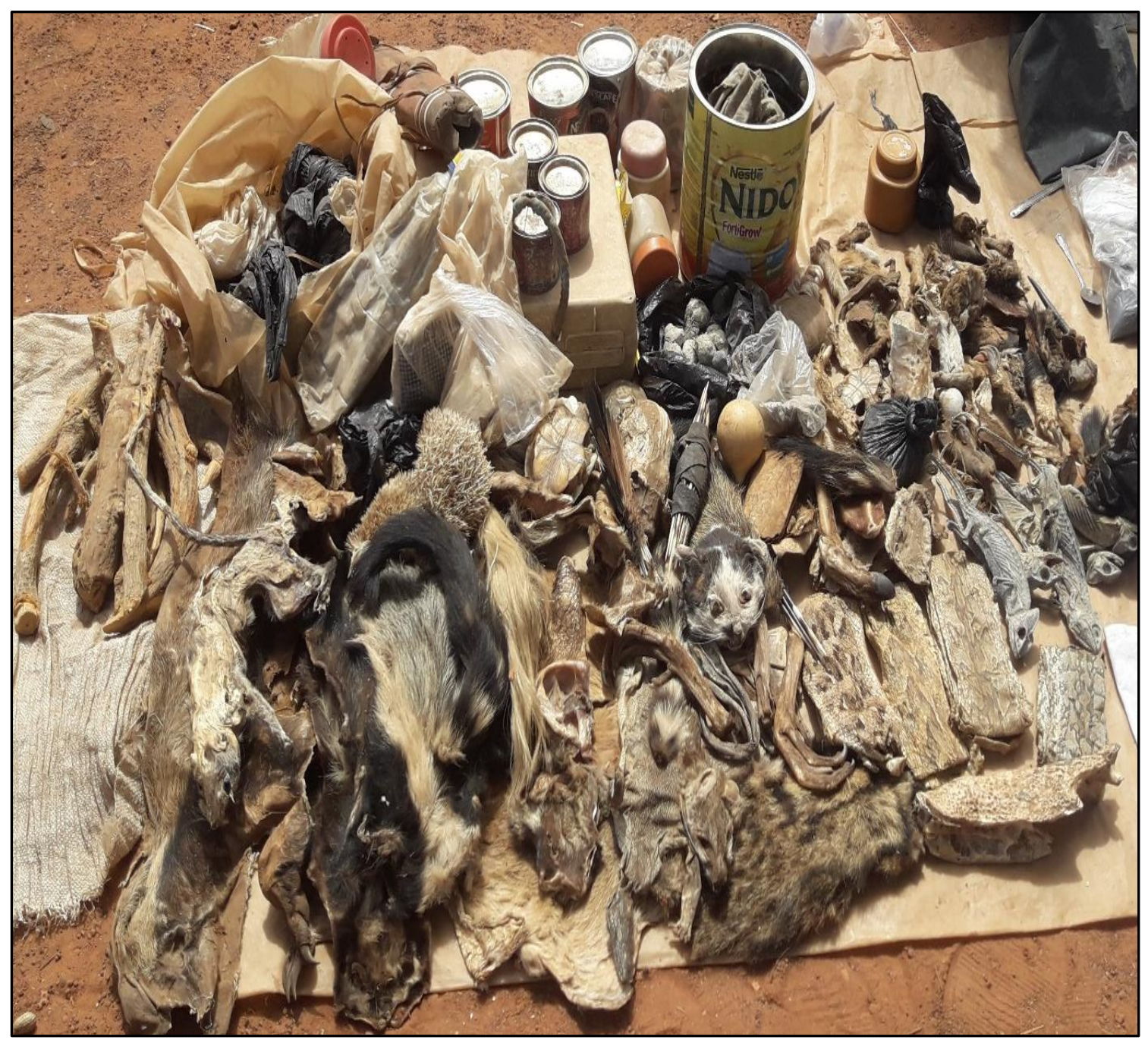

Figure 2: Various products of wildlife exhibited by traditional healers in markets in the Province of Oubritenga (Shot: D. Ouoba, October 2018).

\section{RESULTS}

The wild mammal's species which products are sold in the market

In total, 24 wild mammal species grouped in to 16 families were identified during the survey (Table 2). The most represented families were the Bovidae (4 species) followed by Felidae (3 species), Cercopithecidae, Hyaenidae and Viverridae (2 species each). All the other families are represented by a single species each (Figure 3).
Table 2 also shows that ten (10) species have a use value greater or equal to 0.5 with the species Lepus victoriae (0.83) at the top. The other species have a use value comprise between 0.44 and 0.33 .

\section{The different wild mammals' products sold} in the markets

The survey identified a total of 16 wild mammal products that are traditionally valued in terms of health and mystical practices in the 
province of Oubritenga. Among these products, there are corpses of Crocidura Cinderella and Erinaceus albiventris, fat and droppings (Figure 5).

Users are interested in the skins, the heads, the bones, the horns, the paws, the fats, the tails, the tongues, the ivory, the quills, the penises, the anuses, the hair, the droppings, the jaws, the hooves, the livers or even sometimes the whole animals (Figure 4). According to the interviewees, the skin $(51.30 \%)$ is more frequently used. It is followed by the bones / the horns $(16.23 \%)$, the paws $(7.14 \%)$, the head $(5.19 \%)$ and the whole animal (4.55\%) (Figure $5)$.

\section{The different origins of wild mammals' products sold in the markets}

The products of wild mammals that are sold by the sellers are mainly from Burkina Faso (92.57\%) and Niger (7.43\%). In Burkina Faso, five origins were identified. Following the citation order of importance, they originate from Boinsyaré (39.80\%), Ziniaré (22.60\%), Dori (14.00\%), Fada N'gourma (10.77\%) and Pouytenga (5.40\%) (Figure 6).

These markets are located respectively in the center (the Central region), in the Sahel (the Sahelian region) and in the eastern part (the Eastern region and in Center-East region) of the country.

\section{Diseases treated with the products of wild mammal species}

At the end of the interviews, 21 diseases treated by wild mammals' products were listed (Table 3). The use of Civetticis civetta anus to treat madness and the Loxodonta africana bone to heal stunted children are cited to be the most wanted by the users ( 8 respondents). The least cited are the use of the Syncerus caffer brachyceros tail to heal rib pain and the Erythrocebus patas to heal stomach aches, breast pain, dizziness, coughing (8 respondents).

\section{Mystical practices using the products of wild mammal species}

In total 7 mystical practices using wild mammal products were cited by the sellers (Table 4). These practices involve seven wild mammals' species. Among them, the use of Lepus victoriae tongue to attract "good luck" is the most cited (10 respondents) although the use of the Crocidura cinderella corpse to make "children courageous" is the least cited (2 respondents).

\section{Wild mammals' species conservation status}

Table 5 shows that almost all the species (22 species) listed are entirely protected then forbidden from hunting in Burkina Faso except Hippotragus equinus, Syncerus caffer brachyceros and Panthera leo which are partially protected. According to IUCN (2009) classification, four (04) species is in the category Vulnerable (VU), one species in the category Non-Evaluted (NE) and the rest in the category Least Concern (LC). As for the CITES (2017), only one species is listed on Annex 1 of endangered species (Loxodonta africana) and the remaining species are either on the Annex II, III or on non-evaluated category. 
Table 2: List of wild mammal species identified in the stalls of traditional healers.

\begin{tabular}{|c|c|c|c|}
\hline Families & Scientific names & $\begin{array}{l}\text { Local names } \\
\text { (Mooré) }\end{array}$ & $\mathbf{U}-\mathbf{V}$ \\
\hline \multirow[t]{4}{*}{ Bovidae } & $\begin{array}{l}\text { Hippotragus equinus É. Geoffroy Saint-Hilaire, } \\
1803\end{array}$ & Wilpelogo & 0.44 \\
\hline & Ourebia ourebi Zimmermann, 1783 & Walaga & 0.39 \\
\hline & Sylvicapra grimmia Linnaeus, 1758 & Gnisri & 0.28 \\
\hline & Syncerus caffer brachyceros Gray, 1837 & Wenafo & 0.44 \\
\hline \multirow[t]{2}{*}{ Cercopithecidae } & Chlorocebus aethiops Linnaeus, 1758 & Wâamba & 0.44 \\
\hline & Erythrocebus patas Schreber, 1775 & Wam miga & 0.39 \\
\hline Elephantidae & Loxodonta africana Blumenbach, 1797 & Wobgo & 0.78 \\
\hline Erinaceidae & Atelerix albiventris Wagner, 1841 & Yugempende & 0.33 \\
\hline \multirow[t]{3}{*}{ Felidae } & Felis silvestris Schreber, 1777 & Wegnouga & 0.33 \\
\hline & Panthera leo Linnaeus, 1758 & Bongnega & 0.50 \\
\hline & Panthera pardus Linnaeus, 1758 & Abga & 0.33 \\
\hline Galagonidae & Galago senegalensis É. Geoffroy, 1796 & Luanfidiga & 0.33 \\
\hline Hippopotamidae & Hippopotamus amphibius Linnaeus, 1758 & Yemdé & 0.50 \\
\hline \multirow[t]{2}{*}{ Hyaenidae } & Crocuta crocuta Erxleben, 1777 & Katré & 0.61 \\
\hline & Hystrix cristata Linnaeus, 1758 & Syemde & 0.50 \\
\hline Leporidae & Lepus victoriae Thomas, 1893 & Swamba & 0.83 \\
\hline Muridae & Cricetomys gambianus Waterhouse, 1840 & Rayuuga & 0.44 \\
\hline Mustelidae & Mellivora capensis Schreber, 1776 & Kiègna & 0.39 \\
\hline Orycteropidae & Orycteropus afer Pallas, 1766 & Tantouri & 0.56 \\
\hline Scuiridae & Euxerus erythropus E. Geoffroy, 1803 & Kiiga & 0.33 \\
\hline Soricidae & Crocidura cinderella, Thomas, 1911 & Sabtonsgo & 0.67 \\
\hline Suidae & Phacochoerus africanus Gmelin, 1788 & Reogo & 0.50 \\
\hline \multirow[t]{2}{*}{ Viverridae } & Civettictis civetta Schreber, 1776 & Parignégo & 0.61 \\
\hline & Genetta genetta Linnaeus, 1758 & Piifo & 0.33 \\
\hline
\end{tabular}


D. OUOBA et al. / Int. J. Biol. Chem. Sci. 14(4): 1322-1340, 2020

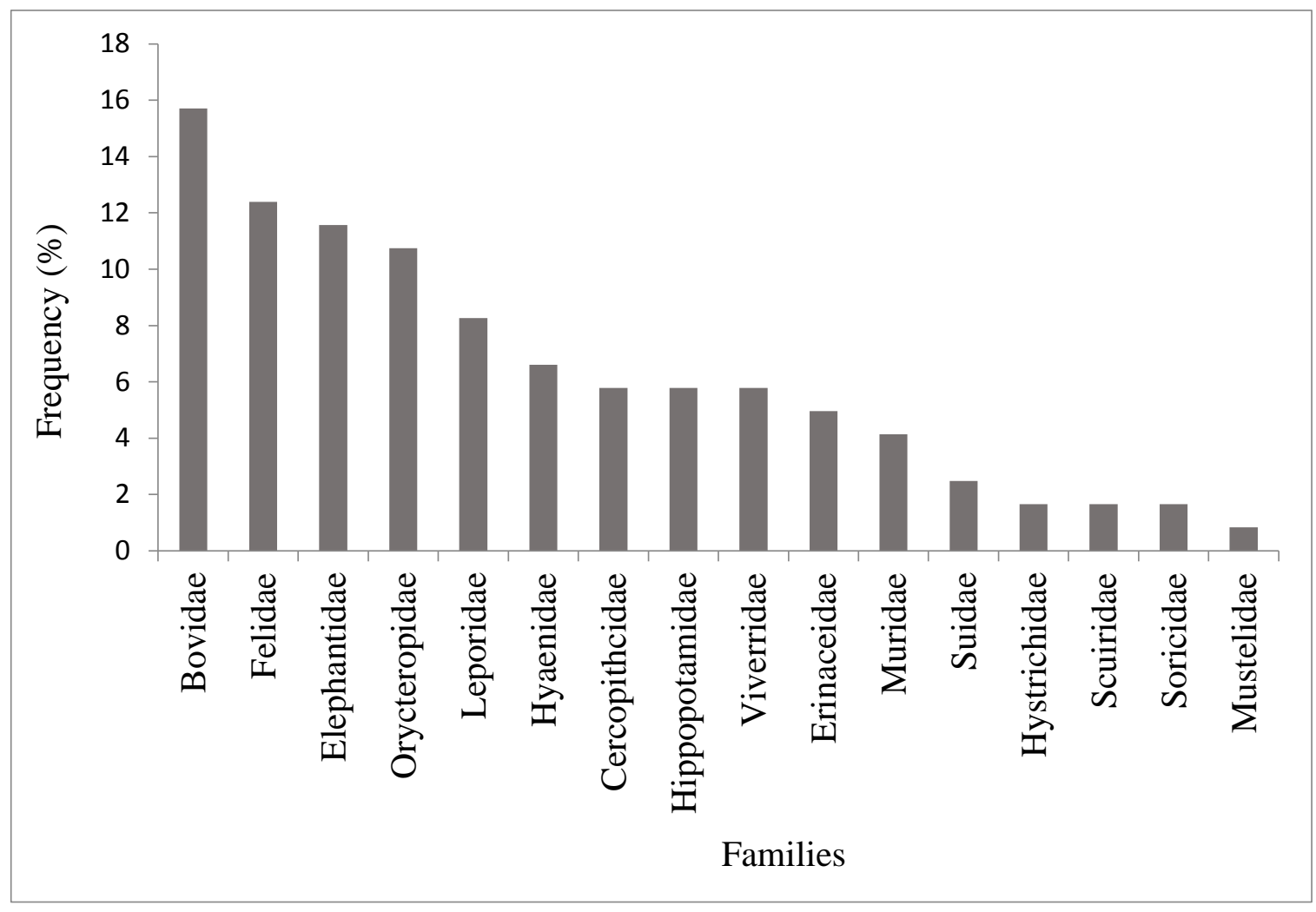

Figure 3: Frequencies of wild mammal's species families listed from traditional healers.
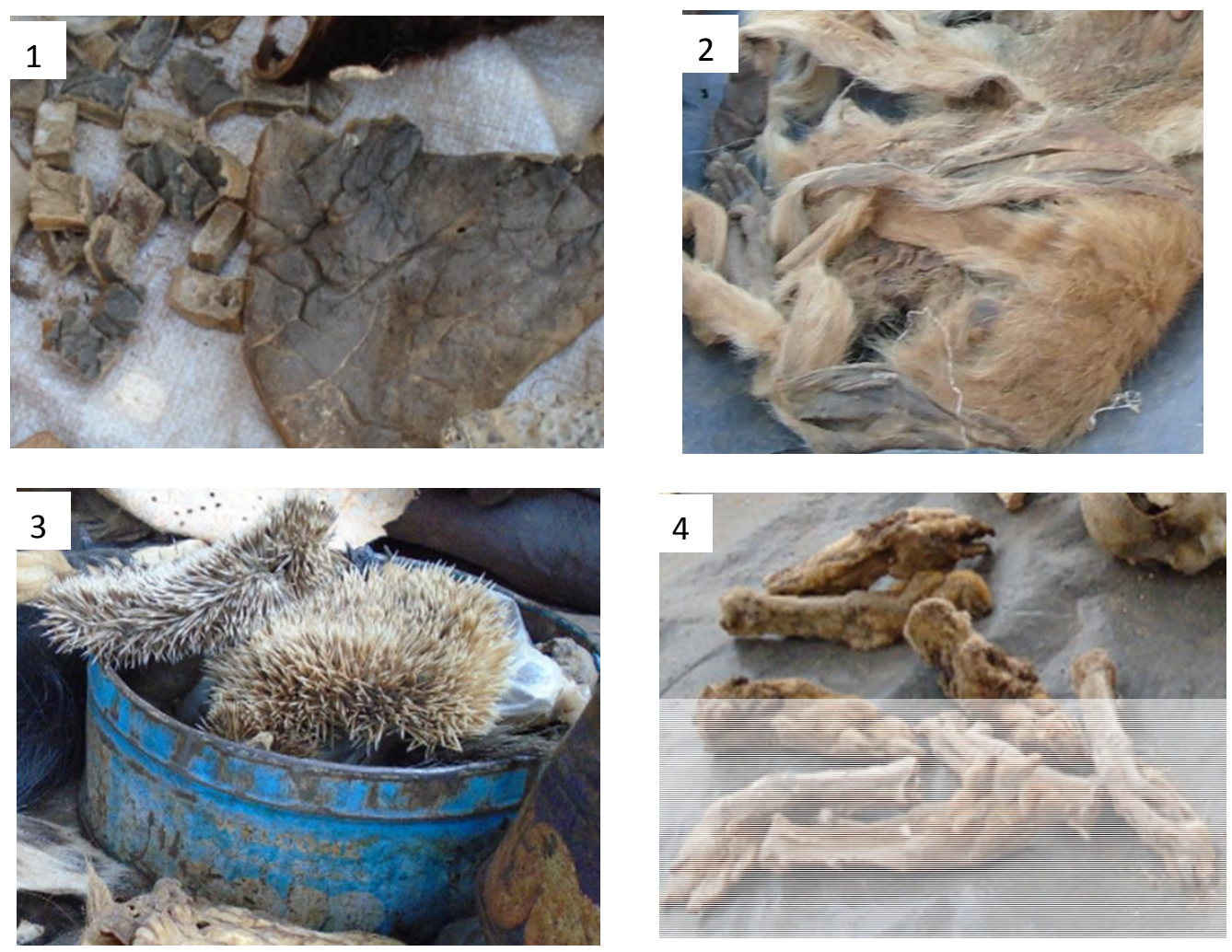

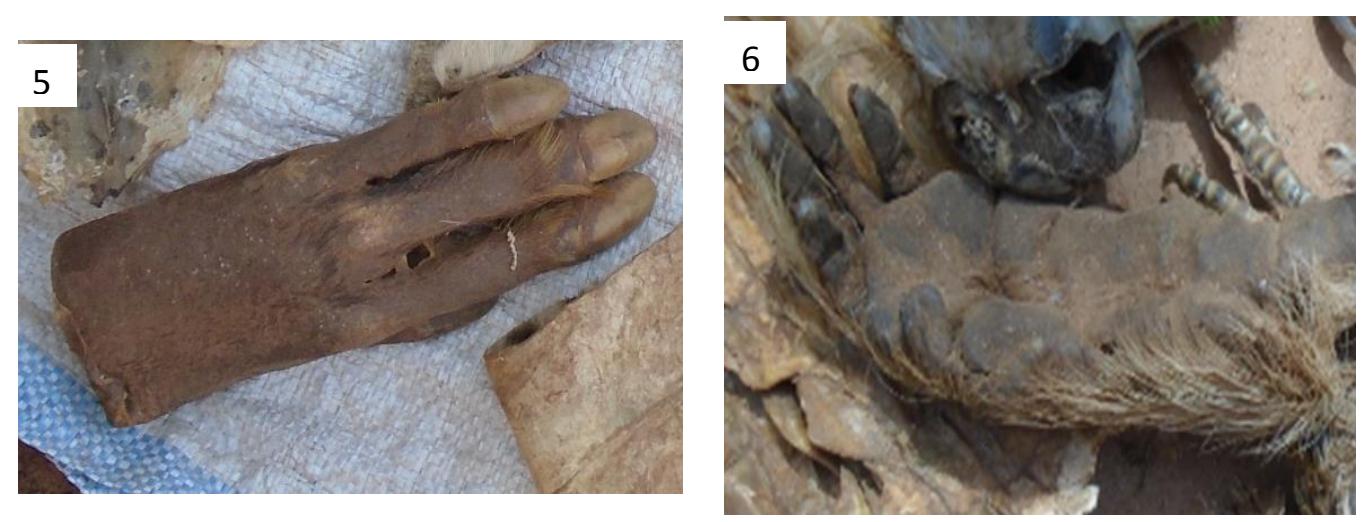

Figure 4: Some products of wild mammal species exhibited by traditional healers in markets for sale (1: Retail trade of cuts of an elephant's skin, 2: Skins of patas, 3: Box with corpses of hedgehogs, 4: Paws of hares, 5: A hand of an aardvark, 6: A hand of a baboon). (Shot: D. Ouoba, October 2018).

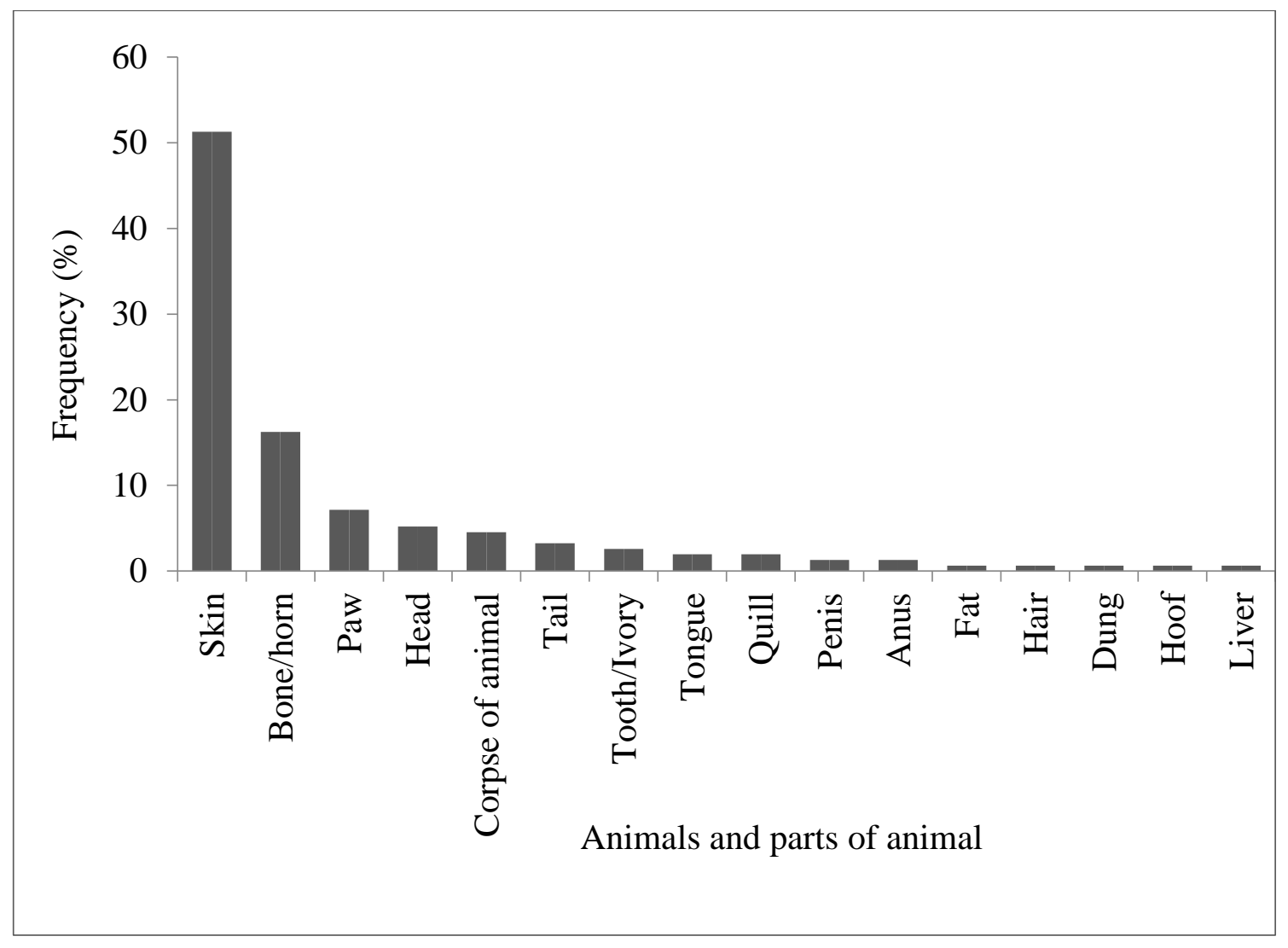

Figure 5: Frequencies of wild mammals' products listed from traditional healers. 


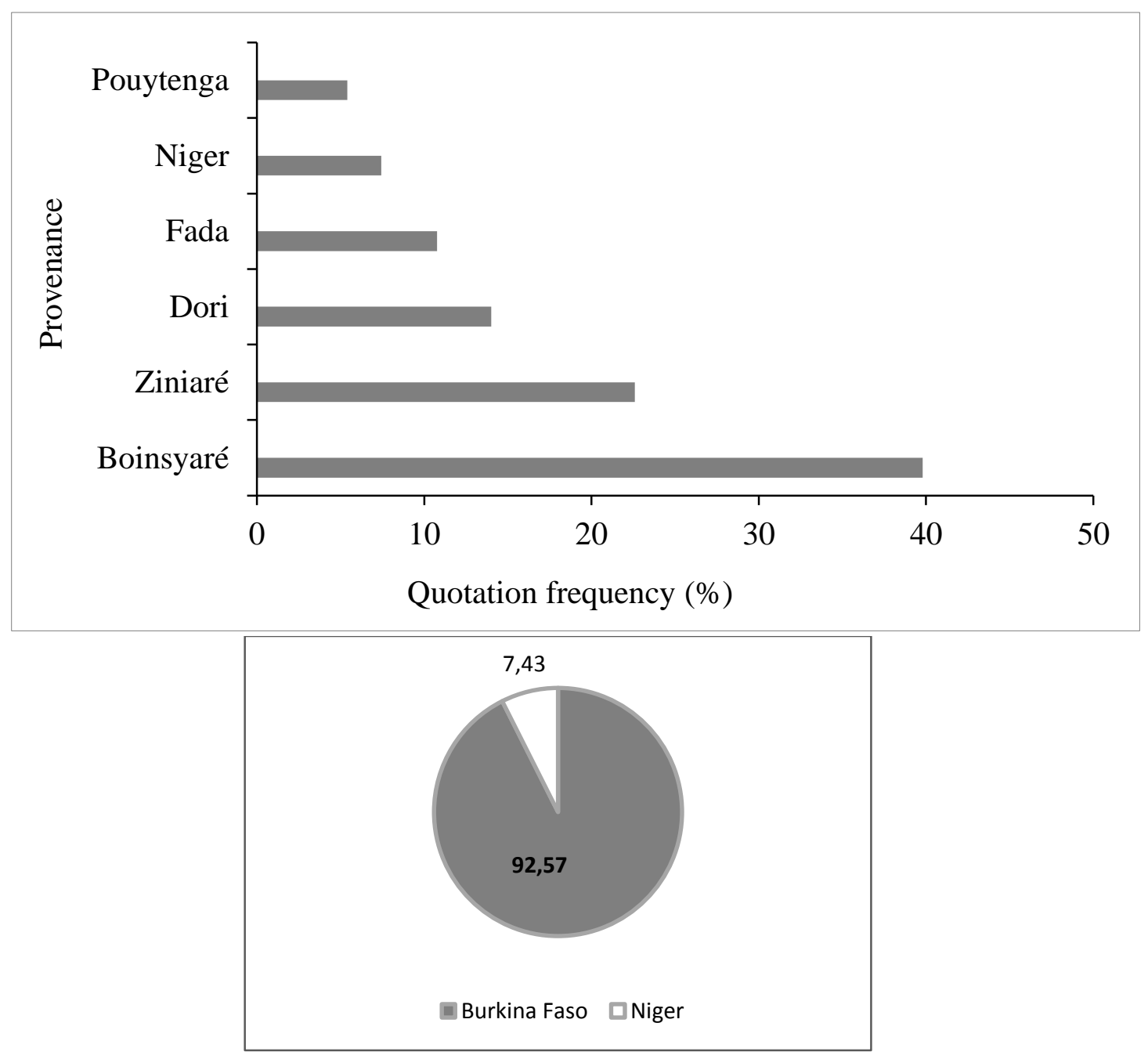

Figure 6: Frequencies of wild mammals 'products origins.

Table 3: List of diseases cured by the products of wild mammal species according to the traditional healers.

\begin{tabular}{lllc}
\hline Diseases treated & Species & Products & $\begin{array}{c}\text { Number of } \\
\text { respondents }\end{array}$ \\
\hline Madness & Civetticis civetta & Anus & 8 \\
Stunted children & Loxodonta africana & Bone & 8 \\
Stomach aches, fatigue & Atelerix albiventris & Corpse & 7 \\
Fragility of children's bones & Panthera leo & Skin & 7 \\
Sore mouth & Hippopotamus amphibius & Tongue & 6 \\
Rheumatism & Hippotragus equinus & Bone & 6 \\
Men's sexual weakness & Hystrix cristata & Penis & 6 \\
Fragility of children's bones, ear pain & Phachoecerus africanus & Fat & 6
\end{tabular}




\begin{tabular}{|c|c|c|c|}
\hline Men's sexual weakness & Syncerus caffer brachyceros & Penis & 6 \\
\hline Migraines & Hystrix cristata & Head & 5 \\
\hline $\begin{array}{l}\text { Stunted children, fragility of children's } \\
\text { bones }\end{array}$ & Phachoecerus africanus & Bone & 5 \\
\hline $\begin{array}{l}\text { Stomach aches, breast pain, dizziness, } \\
\text { coughing }\end{array}$ & Chlorocebus aethiops & Skin & 4 \\
\hline Toothaches & Cricetomys gambianus & Head & 4 \\
\hline Headaches & Hippotragus equinus & Skin & 4 \\
\hline Breast pain & Hystrix cristata & Skin & 4 \\
\hline Wounds, shin pain & Orycteropus afer & Skin & 4 \\
\hline Wounds, dizziness & Ourebia ourebi & Skin & 4 \\
\hline Malaria & Civetticis civetta & Skin & 3 \\
\hline Coughing & Hystrix cristata & Quill & 3 \\
\hline $\begin{array}{l}\text { Stunted children, wounds, shin pain, } \\
\text { malaria, madness }\end{array}$ & Loxodonta africana & Skin & 3 \\
\hline shin pain & Orycteropus afer & Leg & 3 \\
\hline Men’s sexual weakness & Mellivora capensis & Bone & 3 \\
\hline $\begin{array}{l}\text { Men's genital organs' Wounds, Body } \\
\text { wounds }\end{array}$ & Sylvicapra grimmia & Skin & 3 \\
\hline Migraines & Syncerus caffer brachyceros & Bone/horn & 3 \\
\hline $\begin{array}{l}\text { Stomach aches, breast pain, dizziness, } \\
\text { coughing }\end{array}$ & Erythrocebus patas & Skin & 2 \\
\hline Rib pain & Syncerus caffer brachyceros & Tail & 2 \\
\hline
\end{tabular}

Table 4: The Uses of the products of mammalian fauna in mystical practices.

\begin{tabular}{lllc}
\hline Mystical practices & Species & Products & $\begin{array}{c}\text { Number of } \\
\text { respondents }\end{array}$ \\
\hline Transforming a bad luck into a good luck & Lepus victoriae & Tongue & 10 \\
Being protected from curses & Crocuta crocuta & Tongue & 8 \\
Making children courageous & Lepus victoriae & Leg & 8 \\
Providing capacities for mimicry & Panthera leo & Skin & 8 \\
Protecting against poison & Hystrix cristata & Quill & 7 \\
Transforming a bad luck into a good luck & Genetta genetta & Dung & 7 \\
Making children courageous & Crocuta crocuta & Dung & 6 \\
Providing capacities for mimicry & Syncerus caffer brachyceros & Skin & 6 \\
Protecting against machete & Phachoecerus africanus & Tooth & 5 \\
Protecting against genies' and wizards' & Civetticis civetta & Tail & 4 \\
attacks & Syncerus caffer brachyceros & Bone/horn & 4 \\
Transforming a bad luck into a good luck & Hystrix cristata & Head & 3 \\
Making children courageous & Crocidura cinderella & Corpse & 2 \\
Making children courageous & & & \\
\hline
\end{tabular}


Table 5: Conservation Statute of the 25 wild mammal species listed under the legislation of Burkina Faso, the IUCN 2019 red list and the CITES 2017 appendices.

\begin{tabular}{|c|c|c|c|}
\hline Species & $\begin{array}{l}\text { Legislation of } \\
\text { Burkina Faso }^{1}\end{array}$ & $\begin{array}{c}\text { IUCN Red List } \\
\text { Categories }^{2}\end{array}$ & $\begin{array}{c}\text { Appendices of } \\
\text { CITES }^{3}\end{array}$ \\
\hline Hippotragus equinus & IIB & $\mathrm{LC}$ & NL \\
\hline Ourebia ourebi & IIB & $\mathrm{LC}$ & NL \\
\hline Sylvicapra grimmia & IIB & $\mathrm{LC}$ & NL \\
\hline Syncerus caffer brachyceros & IIB & NT & NL \\
\hline Chlorocebus aetiops & IA & $\mathrm{LC}$ & II \\
\hline Erythrocebus patas & IA & $\mathrm{LC}$ & II \\
\hline Loxodonta africana & IA & VU & I \\
\hline Atelerix albiventris & IA & $\mathrm{LC}$ & NL \\
\hline Felis silvestris & IA & $\mathrm{LC}$ & II \\
\hline Panthera leo & IIB & VU & II \\
\hline Panthera pardus & IA & VU & II \\
\hline Galago senegalensis & IA & $\mathrm{LC}$ & II \\
\hline Hippopotamus amphibius & IA & VU & II \\
\hline Crocuta crocuta & IA & $\mathrm{LC}$ & NL \\
\hline Hystrix cristata & IA & $\mathrm{LC}$ & NL \\
\hline Lepus victoriae & IIB & $\mathrm{LC}$ & NL \\
\hline Cricetomys gambianus & IIB & $\mathrm{LC}$ & NL \\
\hline Mellivora capensis & IA & $\mathrm{LC}$ & III \\
\hline Orycteropus afer & IA & $\mathrm{LC}$ & NL \\
\hline Euxerus erythropus & IA & $\mathrm{LC}$ & NL \\
\hline Crocidura cinderella & IA & $\mathrm{LC}$ & NL \\
\hline Phacochoerus africanus & IIB & $\mathrm{LC}$ & NL \\
\hline Civettictis civetta & IIB & $\mathrm{LC}$ & III \\
\hline Genetta genetta & IA & $\mathrm{LC}$ & NL \\
\hline
\end{tabular}

${ }^{1}:$ IA $=$ Fully protected species, no hunting; IIB = Partially protected species, likely to be hunted and captured;

2: $\mathrm{LC}=$ Least concerned, $\mathrm{VU}=$ Vulnerable, $\mathrm{EN}=$ Endangered, $\mathrm{NT}=$ Nearly threatened;

${ }^{3}: \mathrm{I}=$ threatened with extinction, II = species whose specimens trade must be regulated to avoid incompatible exploitation with their survival, III = species that any Party identifies as being subject to regulation within its jurisdiction for the purpose of preventing or restricting their exploitation, and as needing the co-operation of other Parties in the control of trade, NL = Not currently listed). 


\section{DISCUSSION}

The use of wild mammal products in traditional medicine and mystical practices in the Province of Oubritenga concerns 25 species. 16 different products of wild mammal were found on the traditional healers and sellers 'stalls. These products come from Burkina Faso (92.4\%) and Niger (7.6\%). They are used to treat 21 different human diseases. 7 of these products are also used by the population to obtain mystical desired effects. Almost all listed species (22 species) are entirely protected, then forbidden from hunting in Burkina Faso. Only four (4) species are classified in the category "Vulnerable" on the IUCN (2019) red list. Regarding the CITES (2017) classification, Loxodonta africana is an "Endangered species".

As for Burkina Faso, among the 25 species listed in the Oubritenga Province, two are known by the population around the "Ranch de gibier de nazinga" and the "Réserve de biosphère de la mare aux hippopotames" for their importance in pharmacopeia, mystical and cultural practices (Dibloni, 2003; Dibloni et al., 2009; Dibloni, 2013. These species are Hippotragus equinus, Hippopotamus amphibius, Erythrocebus patas, Phacochoerus africanus and Hystrix cristata.

According to Dibloni (2003), the populations around "Ranch de gibier de Nazinga" cited the Hippotragus equinus's organs as being components in the treatment of headaches, malaria, HIV/AIDS. For these populations, the male hippotrague's genital organ combined with other products is an efficient aphrodisiac. In this study, the skin of Hippotragus equinus is used to cure Headaches and Rheumatism, the quill of Hystrix cristata for Coughing, the skin of Erythrocebus patas for stomach aches, breast pain, dizziness and coughing.

In addition, surveys conducted around the "Réserve de biosphère de la mare aux hippopotames" in Burkina Faso, the population confirmed that the burned bones of the Hippopotamus amphibius's tail treat sinusitis. Its skin treats itching (Dibloni, 2011; Dibloni et al., 2013). In the same area, the hands and the tail of the Erythrocebus patas, the hair of the
Phacochoerus africanus and the spine of the Hystrix cristata are used for desired effects (mystical effects and well-being) (Dibloni et al., 2013).

The number of 25 listed mammals in our study area is less than 87,28 and 26 species respectively found Djagoun et al. (2012) on Benin territory, Ajagun and Anyaku (2017) at Ogbomoso in the Oyo State and Jugli et al. (2019) in North-East India. This may be due to several factors like the low number of sellers in the study area, the local unavailability of wildlife resources, the sellers did not show all their products. Another important factor is the loss of traditional knowledge related to medicinal animals caused by the lack of interest of young people for this activity. According to Jugli et al. (2019), the problem is that traditional healers are often reluctant to share their knowledge and young people are nowadays less and less interested in learning about the "old ways".

In this study, 21 different human diseases have been cured by medicinal mammals. This number of diseases is close to 21 diseases found in Brazil (Barbosa et al., 2018). In Ethiopia, it's 18 different diseases that have been listed. (Yirga et al., 2011). This high number of diseases proves that populations conserve their traditional knowledge despite the effectiveness of modern medicine. On the other hand, poverty pushes population to have recourse to this traditional medicine which is generally available and affordable for all (Rivière et al., 2005; Jugli et al., 2019). Finally, this could explain the inefficiency of modern medicine regarding certain human diseases (Azanlin, 2015; Jugli et al., 2019). The study has also reported 7 mystical practices related to wild mammals identified in the area of study. For example, the tooth of Phacochoerus africanus is used to strengthen the body and resist machete attacks, the tail of Civetticis civetta to protect against genies and wizards' attacks. In literature, similar traditional practices have been recorded. For example, the heart of the Syncerus caffer brachyceros makes a person brave in scary situations, its horn and its tail are respectively used to counter the sorcerer 
attacks and malediction (Azanlin, 2015). Parts of' Hippopotamus amphibius are used to free people from bewitchment in Nigeria (Ajagun et al., 2017).

The wild mammal products sellers get their supplies from Burkina Faso and Niger. Burkina Faso is the main supplier. These results confirm similar previous research (Djagoun et al., 2012; Ogoanah and Omijie, 2017). That means that the supply chain does not end in Burkina Faso but also concerns other countries. Indeed, the markets of wild fauna products are found all over the world and are supplied by a strong traffic. This traffic is an organized network and often international (Alves and Alves, 2011; Whiting et al., 2011; Ferreira et al., 2013).

According to the study, many listed species are forbidden to hunt in Burkina Faso. Among these species, 4 are vulnerable species according to IUCN (2019). These results are close to those of Djagoun et al. (2012). It shows that the utilization of wild mammals in traditional medicine and mystical practices are a threat to these species. This threat in Burkina is a general fact in the world because it is cited in IUCN 2019 red list.

The list of the 25 identified species in this study is not exhaustive because it only concerns species that are formally identified. Those for which there were relevant doubts, were declared undetermined and unclassified in this study. DNA test on the unclassified species should allow to obtain a complete list. Additionally, the results regarding mystical practices and the diseases treated by wild mammals are statements based on experiences transmitted from generation to generation. Future researches might be oriented on the isolation and the experimentation of the active principles of the medicinal wild mammals.

The study showed that many of the wild mammal species which products are sold in the markets are forbidden to hunt in Burkina Faso. These biological and genetic resources came from an unsustainable exploitation of wild fauna. The activity is illegal, and actors do not have technical and scientific support until now. It may cause biodiversity loss because according to Djagoun et al. (2012), the non- sustainable use of medicinal animals is a potential threat for species survival.

This fact raises several questions: (i) the ineffectiveness of regulatory texts for the exploitation and the marketing of wildlife products or the application of these texts; (ii) the ignorance of the negative impacts of their activity on the wild fauna in general and on rare or endangered species in particular and also (iii) the frustrations of the populations caused by the unfair benefits sharing arising from the exploitation of these wildlife resources.

Ogoanah and Omijie (2017) points out that, if the activity persists and even increases because of the demand, this could be due to an inadequate enforcement of the law in the field of wildlife. According to Costa-Neo (2005), environmental policies and measures taken against the trade of medicines originated from animals should also take into account the lucrative nature of the activity for practitioners. As for Djagoun et al. (2012), instead of sending animal therapy practitioners to prisons or creating policies aimed at forcing traders to abandon such practices, decision-makers should try to contextualize this form of human / nature link in its cultural dimension.

Since the users of these wildlife products find satisfaction in their practices, it is imperative to reconcile these needs with the need to conserve the concerned species. To achieve this, it would be necessary to deepen the researches on the biology of medical animal species and the biochemical composition of the healing organs and parts of these species. For the moment, it is urgent to organize and supervise the different actors, raise awareness and educate them on the need to conserve these wildlife resources. The populations must understand that the preservation of their traditional knowledge on animals and their products to treat diseases and perform mystical practices depends on the availability of the raw material, i.e. animals (Jugli et al., 2019). In addition, as recommended by Ouoba (2009), i) in order to avoid the poaching of these species, it would be wise to involve the associations of traditional healers during hunting periods so that they recover products that are not generally not consumed and, ii) initiatives should be 
developed for the promotion of the most used species such as the lion and the aardvark and others.

\section{Conclusion}

This study concludes that wild mammals play an important role in traditional medicine and mystical practices for local communities in Oubritenga province. It inventoried 16 different products of 25 species of wild mammals. The interviews revealed that these products are used by populations to treat 21 human diseases and carry out 7 mystical practices. These products come from Burkina Faso $(92.4 \%)$ and Niger $(7.6 \%)$. Among the inventoried species, 22 are fully protected by the law of Burkina Faso, 4 are vulnerable according to IUCN criteria. This data will help biodiversity managers to better design strategies for conservation and sustainable use of wildlife in Burkina Faso.

\section{COMPETING INTERESTS}

The authors declare that they have no competing interests.

\section{AUTHORS' CONTRIBUTIONS}

DO and OTD developed the research protocol. DO and YO collected the data. DO and OTD analysed the data. DO wrote the manuscript. OTD, KM and BGK revised the manuscript.

\section{ACKNOWLEDGMENTS}

We would like to thank the Regional Directorate in charge of the Environment of the "Plateau-Central", and all the traditional healers for their precious collaboration.

\section{REFERENCES}

Ajagun EJ, Anyaku CE. 2017. Conservation Status of Animal Species Used by Indigenous Traditional Medicine Practitioners in Ogbomoso, Oyo State, Nigeria. Journal of Complementary and Alternative Medical Research, 3(4): 1-8. DOI: 10.9734/JOCAMR/2017/36018.

Alade GO, Frank A, Ajibesin K. 2018. Animals and animal products as medicines: A survey of Epie-Atissa and Ogbia people of Bayelsa State, Nigeria. Journal of Pharmacy \& Pharmacognosy Research, 6 (6): 483-502. http://jppres.com/jppres

Albuquerque UP, Cruz da Cunha LVF, Paiva de Lucena RF, Alves, RRN. 2014. Methods and Techniques in Ethnobiology and Ethnoecology. Springer: New York, USA. DOI: 10.1007/978-1-4614-8636-7.

Albuquerque UP, Medeiros PM, Almeida AL, Monteiro JM, LinsNeto EMF, Melo JG, Santos JP. 2007. Medicinal plants of the caatinga (semi-arid) vegetation of $\mathrm{NE}$ Brazil: a quantitative approach. $J$. Ethnopharmacol, 114: 325-354. DOI: 10.1016/j.jep.2007.08.017.

Alves RRN, Alves HN. 2011. The faunal drugstore: animal-based remedies used in traditional medicines in Latin America. $J$. Ethnobiol Ethnomed, 7(1): 9. DOI: 10.1186/1746-4269-7-9.

Alves RR, Rosa IL, Neto NAL, Voeks R. 2012. Animals for the gods: magical and religious faunal use and trade in Brazil. Human Ecology, 40 (5): 751780. DOI: 10.1007/s10745-012-9516-1.

Azanlin MS. 2015. Ecologie et considérations ethnozoologiques du buffle (Syncerus caffer) au sud et au centre du Bénin. Thèse de Doctorat Unique. Université d'Abomey-Calavi, Cotonou, Bénin, p. 164.

Barbosa JAA, Aguiar JO, Alves RRN. 2018. Medecinal use of animals by hunters in North eastern Brazil. Indian Journal of Traditionnal Knowledge, 17 (3): 485493.

https://www.researchgate.net/publication 1330894493.

Bruce H, Timothy G. 2007. Importance Indices in Ethnobotany. Ethnobotany Research \& Applications, $\quad$ 5: 201-218. http://ethnobotanyjournal.org/index.php/ era/article/view/130.

Camino M, Cortez S, Altrichter M, Matteucci DS. 2018. Relations with wildlife of Wichi and Criollo people of the Dry Chaco, a conservation perspective. Ethnobiology and Conservation, 7:11. DOI: 10.15451/ec2018-08-7.11-1-21. 
Castillo L, Ladio AH. 2019. Zootherapy and rural livestock farmers in semiarid Patagonia: the transfer of animal aptitudes for health. Ethnobiology and Conservation, 8: $2 . \quad$ DOI: 10.15451/ec2019018.02124.

Cetto AA, Heinrich M. 2011. From the field into the lab: useful approaches to selecting species based on local knowledge. Coyoacán, México. Frontiers in Pharmacology, 20(2): $1-5 . \quad$ DOI: 10.3389/fphar.2011.00020.

CITES (Convention on International Trade in Endangered Species of wild fauna and flora). 2017. The CITES Appendices I, II \& III. Version 2017-10-04.

Costa-Neto EM. 2005. Animal-based medicines: biological prospection and the sustainable use of zootherapeutic resources. An Acad Bras Cienc, 77(1): 33-43.

DOI: $10.1590 / \mathrm{s} 0001-$ 37652005000100004.

Dibloni OT. 2003. Dynamique des populations d'hippotragues (Hippotragus equinus) et de bubales (Alcelaphus buselaphus) au Ranch de Gibier de Nazinga (Burkina Faso). Mémoire de Fin d'études approfondies en Sciences Agronomiques et Ingénierie biologique. Faculté Universitaire des Sciences Agronomiques De Gembloux. p. 110.

Dibloni OT. 2011. Impact des activités anthropiques sur la dynamique de la faune sauvage dans la réserve de biosphère de la mare aux hippopotames en zone sud soudanienne du Burkina Faso : cas de l'hippopotame commun (Hippopotamus amphibius L.). Thèse de Doctorat unique de l'Université de Ouagadougou, Burkina Faso, p. 151.

Dibloni OT, Coulibaly ND, Guenda W, Vermeulen C, Belem/Ouédraogo M. 2009. Caractérisation paysanne de l'hippopotame commun, Hipppopotamus amphibius Linné 1758, dans la Réserve de la Biosphère de la Mare aux Hippopotames du Burkina Faso. Int. J. Biol. Chem. Sci., 3(2): 386-397. DOI: $10.4314 /$ ijbcs.v3i2.44515.
Dibloni OT, Guenda W, Belem/Ouédraogo M, Poda JN. 2013. Ethnozoology applied to the Hippopotamus Pond, Biosphere Reserve in the South-Sudanese Zone of Burkina Faso. In Biosphere Reserves in Sub-Saharan Africa Showcasing Sustainable Development, Pool-Stanvliet R, Clüsener-Godt M (eds). AfriMAB; 162-182.

Dibloni OT, Coulibaly ND, Ouédraogo L, Yaméogo D. 2019. Caractérisation ethnozoologique des populations du bubale major dans la Forêt Classée et Ranch de gibier de Nazinga au Burkina Faso. Science et Technique, Sciences Naturelles et Appliquée, 38(2) : 117-130. Djagoun CAMS, Akpona HA, Mensah GA, Nuttman C, Sinsin $\quad$ B. 2012. Wild Mammals Trade for Zootherapeutic and Mythic Purposes in Benin (West Africa): Capitalizing Species Involved Provision Sources, and Implications for Conservation. In Animals in Traditional Folk Medicine, Alves RRN, Rosa IL (eds.). Springer-Verlag: Berlin Heidelberg, Germany; 367-381. DOI: 10.1007/978-3-642-29026-8_17.

Djagoun CAMS, Sogbohossou EA, Kassa B, Akpona HA, Amahowe IO, Djagoun J, Sinsin B. 2018. Trade in primate species for medicinal purposes in southern Benin: implications for conservation. TRAFFIC Bulletin, 30 (2): 48-56.

El-Hilal J, Hmammouchi M, Badiâa L. 2003. Ethnobotanical studies and economic evaluation of medicinal plants in Taounate province (Northern Morocco). J. Ethnopharmacol, 86: $149 \quad-158$. DOI: 10.1016/s0378-8741(03)00012-6.

Ferreira FS, Fernandes-Ferreira H, Leo NN, Brito SV, Alves RRN. 2013. The trade of medicinal animals in Brazil: current status and perspectives. Biodiversity and Conservation, 22: 839-870. DOI: 10.1007/s10531-013-0475-7

Friedman J, Yaniv Z, Dafni A, Palevitch D. 1986. A preliminary classification of the healing potential of medicinal plants, based on a rational analysis of an ethnopharmacological field survey 
among bedouins in the Negev desert, Israel. J. Ethnopharmacol, 16: 275-287. DOI: 10.1016/0378-8741(86)90094-2.

Haltenorth T, Diller H, Cuisin M. 1985. Mammifères d'Afrique et de Madagascar. Delachaux et Niestlé, Paris. 397p.

INSD (Institut National de la Statistique et de la Démographie). 2009a. Projections démographiques de 2007 à 2020 par région et province au Burkina Faso.

INSD (Institut National de la Statistique et de la Démographie). 2009b. Monographie de la région du plateau centrale au Burkina Faso.

INSD (Institut National de la Statistique et de la Démographie). 2015. Rapport enquête multisectorielle continue: profil de pauvreté et d'inégalités dans la région du Plateau-central au Burkina Faso.

IUCN (International Union for the Conservation of Nature). 2019. The IUCN red list of Threatened Species. Version 2019-2.

Jugli S, Chakravorty J, Meyer- Rochow BV. 2019. Zootherapeutic uses of animals and their parts: an important element of the traditional knowledge of the Tangsa and Wancho of eastern Arunachal Pradesh, North-East India. Envoronment, Development and Sustainability, 1-36. DOI: 10.1007/s10668-019-00404-6.

Kaboré A, Tamboura HH, Belem AMG, Traoré A. 2007. Traitements ethno-véterinaires des parasitoses digestives des petits ruminants dans le Plateau-central du Burkina Faso. Int. J. Biol. Chem. Sci., 1(3) :

297-304.

DOI: 10.4314/ijbcs.v1i3.39711.

Kakati LN, Bendang AO, Doulo, V. 2006. Indigenous Knowledge of zootherapeutic uses of vertebrate origin by the Ao tribe of Nagaland. Journal of Human Ecology, 19(3):

163-167.

DOI: $10.1080 / 09709274.2006 .11905874$

Kpétéré J, Nago SGA, Natta AK, Houessou L, Kéita NT. 2015. Connaissances ethnozoologiques et importance de l'hippopotame commun (Hippopotamus amphibius amphibius) pour les populations du Nord-Est Bénin:
Implication pour sa conservation et sa valorisation durable. Ann. UP, série Sci. Nat. Agron., 5 (1) : 54-67.

Kouao ML, Bene JCK, Koffi AD, Kouame BA, Kone I. 2018. Caractérisation des dégâts provoqués par la faune sauvage à la périphérie de la Forêt des Marais TanoeEhy au sud-est de la Côte d'Ivoire, Int. J. Biol. Chem. Sci., 12(4): 1717-1730. DOI: https://dx.doi.org/10.4314/ijbcs.v12i4.16

Lamarque F. 2004. Les grands Mammifères du complexe W.A.P. Ouagadougou, Burkina Faso.

Martinez GJ. 2013. Use of fauna in the traditional medicine of native Toba (qom) from the Argentine Gran Chaco region: an ethnozoological and conservationist approach. Ethnobiology and Conservation, 2(2): 1-43. DOI: 10.15451/ec2013-8-2.2-1-43.

McNamara J, Rowcliffe M, Cowlishaw G, Alexander JS, Ntiamoa-Baidu Y, Brenya A, Milner-Gulland EJ. 2016. Characterising Wildlife Trade Market Supply-Demand Dynamics. PLOS ONE, 11(9): e0162972. DOI: 10.1371/journal.pone.0162972.

MEEVCC (Ministère de l'Environnement, de l'Economie Verte et du Changement Climatique). 2017. Décret $\mathrm{n}^{\circ} 2017$ 0238/PRES/PM/MEEVCC du 24 avril 2017 portant liste $\mathrm{A}$ et $\mathrm{B}$ de protection des espèces fauniques. Ouagadougou, Burkina Faso.

Mittermeier RA, Ratsimbazafy J, Rylands AB, Williamson L, Oates JF, Mbora D, Ganzhorn JU, Rodríguez-Luna E, Palacios E, Heymann EW, Kierulff CM, Yongcheng Y, Supriatna J, Roos C, Walker S, Aguiar JM. 2007. Primates in Peril: The World's 25 Most Endangered Primates, 2006 - 2008. Primate Conservation, 1(22): 1-40. DOI: https://doi.org/10.1896/052.022.0101.

Nasi R, Taber A, Van-Vliet N. 2011. Empty forests, empty stomachs? Bushmeat and livelihoods in the Congo and Amazon Basins. I. Forestry Review, 13(3): 355368.

DOI: 
https://doi.org/10.1505/14655481179829 3872.

FAN (Fondation des Amis de la Nature). 2003. Guide de découverte du parc national de Pô, NATURAMA, Burkina Faso, 140 p.

Ogoanah OS, Omijie F. 2017. Animal Species Used for Traditional Medicine in Benin City, Nigeria. Society for Experimental Biology of Nigeria, 17(4): 148-158.

Ouoba Y. 2019. Valorisation traditionnelle des produits et sous-produits de la faune sauvage dans la province de l'Oubritenga, Région du Plateau Central. Mémoire de fin de cycle d'Inspecteur des Eaux et Forêts, Ecole Nationale des Eaux et Forêts, Burkina Faso, 63 p.

Phillips O, Gentry AH. 1993a. The useful plants of Tambopata, Peru: I. Statistical hypotheses tests with a newquantitative technique. Econ. Bot., 47: 15-32. DOI: https://www.jstor.org/stable/4255479.

Phillips O, Gentry AH. 1993b. The useful plants of Tambopata, Peru: II. Statistical hypotheses tests with a new quantitative technique. Econ. Bot., 47: 33-43. DOI: 10.1007/BF02862204.

Rivière C, Nicolas JP, Caradec ML, Desirea O, Hassan DA, Rémy G, Dupont F. 2005. Importance de l'identification botanique dans la démarche ethnopharmacologique; cas d'une Bignoniaceae malgache, Perichlaena richardii Baill. Acta Botanica Gallica, 152(3): 377-388. DOI: 10.1080/12538078.2005.10515496.

Tamboura H, Kaboré H, Yaméogo SM. 1998. Ethnomédecine vétérinaire et pharmacopée traditionnelle dans le plateau central du Burkina Faso: cas de la province du Passoré. Biotechnologie, Agronomie, Société et Environnement, 2 (3): 181-191. http://www.pressesagro.be/base/text/v2n 3/18.pdf.
Whiting MJ, Williams VL, Hibbitts TJ. 2011. Animals traded for traditional medicine at the Faraday market in South Africa: species diversity and conservation implications. Journal of Zoolog, 284: 8496. DOI: 10.1007/978-3-642-290268_19.

Vieira KS, Vieira WLS, Alves RRN. 2014. An Introduction to Zoological Taxonomy and the Collection and Preparation of Zoological Specimens. In Methods and Techniques in Ethnobiology and Ethnoecology, Albuquerque, UP, Cruz da Cunha LVF, Paiva de Lucena RF, Alves RRN (eds). Humana Press: New York, USA; 175-196. DOI: 10.1007/978-14614-8636-7.

Yaokokore-beibro HK, Kasse BK, Soulemane O, Koue-bi MT, Kouassi PK, Foua-bi K. 2010. Ethnozoologie de la faune mammalogique de la forêt classée de Badenou (Korhogo, Côte-d'Ivoire). Agronomie Africaine, 22 (2): 185 -193.

Yirga G, Teferi M, Gebreslassea Y. 2011. Ethnozoological study of traditional medicinal animals used by the people of Kafta-Humera District, Northern Ethiopia. International Journal of Medicine and Medical Sciences, 3(10): 316-320. DOI: 10.5897/IJMMS.

Yolidje I, Da K, Moussa I, Toumane A, Bakasso S, Saley K, Much T, Pirat JL, Ouamba MJ. 2020. Enquête ethnobotanique sur les plantes utilisées traditionnellement au Niger dans la lutte contre les moustiques vecteurs des maladies parasitaires. Int. J. Biol. Chem. Sci., 14(2): 570-579. DOI: https://dx.doi.org/10.4314/ijbcs.v14i2.2. 